\title{
今月の症例
}

\section{凝固異常・消化器症状を呈したsystemic mastocytosis}

\begin{tabular}{|c|c|c|c|c|c|}
\hline 小川 一英 & 阿久津和子 & 七島 晶子 & 池田 & 和彦 & 野地 \\
\hline 眞下由美子 & 高橋＼cjkstart裕志 & 石橋＼cjkstart敏幸 & 竹石 & 恭知 & \\
\hline
\end{tabular}

概要 症例は 42 歳, 男性. 腹痛, 大量の下痢の後, ショック状態となり入院. 入院時PT $10 \%, \mathrm{APTT}$ 180 秒以上で著明な出血症状を認めた．臨床症状，凝固異常は翌日には自然に回復傾向を示したが，そ の後 1 年に渡り腹痛, 下痢, 凝固異常を発作的に繰り返した. 診断に苦慮したが, 血漿トリプターゼが $198 \mu \mathrm{g} / l$ と異常高值, 骨髄検査にてc-kit陽性, CD2 陽性の肥満細胞の集簇を認め, 全身性肥満細胞症systemic mastocytosis と診断した。凝固異常, 消化器症状は, 肥満細胞からのヘパリンやセロトニンなど のメディエーターによる可能性が考えられた.

〔日内会誌 98：141〜143，2009〕

Key words : systemic mastocytosis, 肥満細胞, 凝固異常

症例

患者: 42 歳, 男性. 主訴: 腹痛, 下痢. 既往 歴：20歳時バイク事故で摘脾. 35 歳頃から腹痛, 動悸後に下痢とともに四肢の脱力を自覚する発 作が時々見られていた。家族歴：特記すべきこ となし. 現病歴：2004 年 11 月中旬 0 時 30 分頃, 突然, 動悸, 腹痛が出現し大量の下痢の後意識 消失. 倒れているのを家人に発見されA病院に搬 送された。搬送時血圧触知不能であったが，補 液, カテコールアミンで血圧 $80 \mathrm{mmHg}$ 台に改善 した。低カリウム血症（K $2.4 \mathrm{mEq} / l$ ) を認めた ため, 当初周期性四肢麻痺が疑われ同院神経内 科に入院となった. 入院時血液検査でPT $10 \%$, APTT 180 秒以上と著しい凝固異常が見られた が，約 12 時間後の検査でPT 33\%，APTT 88.6
秒と自然に改善傾向を示した. しかし，採血部 位や中心静脈穿刺部位からの出血や鼻出血が続 きHbが $5 \mathrm{~g} / \mathrm{dl}$ 台まで低下したため濃厚赤血球輸 血を行った. 第 4 病日には凝固検査は正常化し, 全身状態も改善したため, 第 13 病日に同院を退 院, 凝固異常精查目的に 12 月下旬当科紹介となっ た. 初診時現症 : 身長 $173.1 \mathrm{~cm}$, 体重 $62.2 \mathrm{~kg}$, 体温 $36.8^{\circ} \mathrm{C}$, 血圧 $110 / 70 \mathrm{mmHg}$, 脈拍 $60 /$ 分, 胸・腹部：異常所見なし, 浮腫なし, 表在リン パ節触知せず, 神経学的異常所見なし, 皮疹な し. 初診時検査所見：WBC 9,700/ $\mu \mathrm{l}, \mathrm{Hb} 12.8 \mathrm{~g} /$ $\mathrm{dl}, \mathrm{PT} 122.2 \%$, APTT 32.4 秒と正常. その他の 止血・凝固系検査, 生化学的検査も異常を認め なかった. 臨床症状, 検査所見などからカルチ ノイド症候群, ポルフィリン症, WDHA (watery

〔第 184 回東北地方会 $(2008 / 02 / 16)$ 推薦〕受稿 2008/08/05, 採用 2008/08/05]

Systemic mastocytosis with coagulation abnormalities and gastrointestinal symptoms.

Kazuei Ogawa ${ }^{1}$, Akiko Shichishima ${ }^{1}$, Kazuhiko Ikeda ${ }^{1}$, Hideyoshi Noji ${ }^{1}$, Toshiyuki Ishibashi ${ }^{1}$, Yuko Hashimoto ${ }^{2}$ and Yasuchika Takeishi1) ${ }^{1}{ }^{1}$ The First Departments of Internal Medicine and ${ }^{2)}$ Pathology, Fukushima Medical University, Fukushima. 


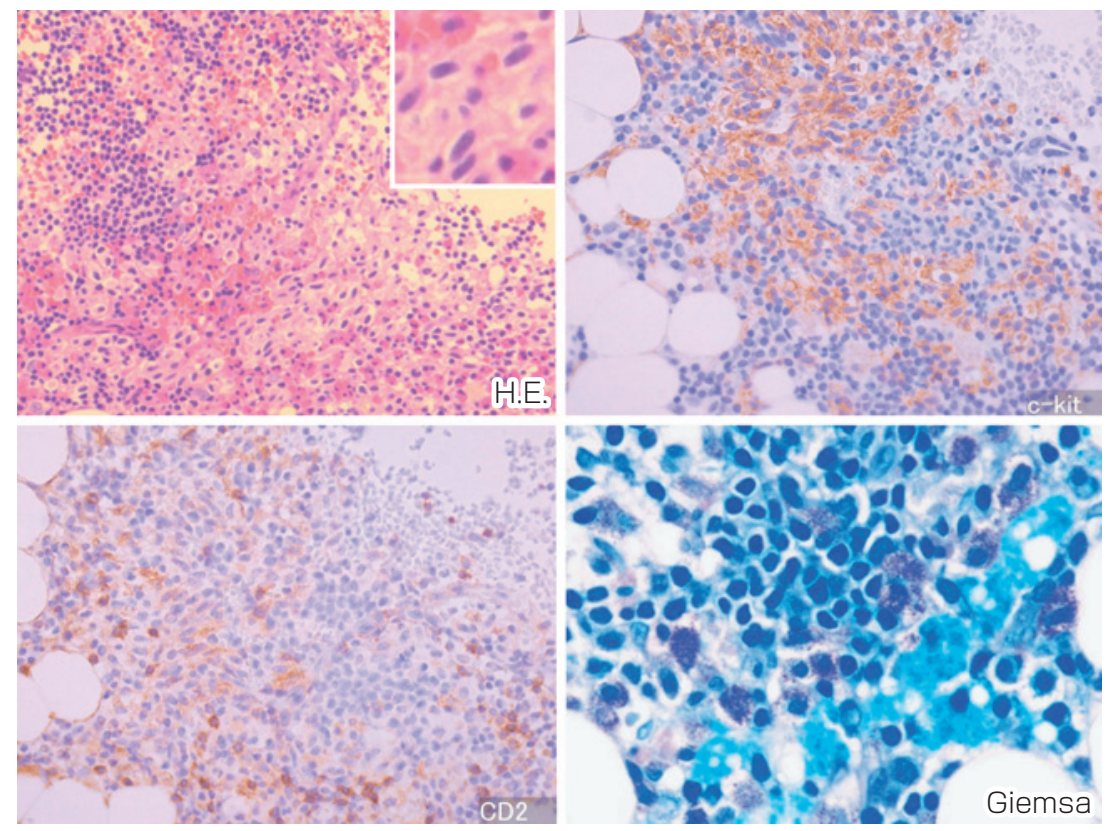

図 . 造血細胞巣内に, 比較的豊かな淡明な胞体を有する肥満細胞の集簇が散見さ れる (HE 染色). 多稜形から類円形肥満細胞に加え, 紡鍾形細胞も認められる. こ れらの細胞は c-kit 陽性, CD2 陽性を示し, Giemsa 染色で胞体内好塩基性顆粒 が観察される.

diarrea, hypokalemia and achlorhydria) 症候群

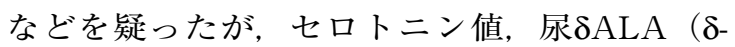
aminolevulinic acid), コプロポルフィン, VIP （vasoactive intestinal peptide）值は，すべて正 常であり, 消化管内視鏡検査, 腹部CT検査, PET 検査でも異常所見は認められなかった。また， 甲状腺, 副腎機能も正常であった.

\section{臨床経過}

本症例は, 診断確定まで約 1 年を要したが, その間, 7 回同様の発作を繰り返し, 救急外来を 受診した，程度の差はあるものの，いずれの発 作も突然の下腹部痛と大量の水様性下痢がみら れ, 共通する検査所見として, PT, APTT延長 などの凝固異常, 低カリウム血症がみられた. 腹痛，下痢などの症状は, 救急外来到着後間も なく消失し，凝固異常も翌日には正常化してい た. 診断の糸口がつかめないまま, 発作を繰り 返すことになったが，発作時の様子を詳しく聴 取すると, 発作時はケミカルメディエーターに
よることを思わせる指先などの痒み, 顔面紅潮 を必ず伴うことが判明した，皮疹は経過を通し て認められなかったが，肥満細胞による疾患を 疑い，血漿トリプターゼを測定したところ，198 $\mu \mathrm{g} / l(2.1 \sim 9.0 \mu \mathrm{g} / l)$ と著しい高值であることが 判明した。ささらに，骨髄穿刺検查で図に示すよ うに著しい肥満細胞の集簇がみられ，その部位 に一致してc-kit, CD2 が陽性を示したため, 全 身性肥満細胞症systemic mastocytosis, SM と確 定診断した.

\section{考察}

肥満細胞が 1 つ以上の臓器において異常増殖, 蓄積する疾患を肥満細胞症と呼び，皮膚に限局 するもの以外の病型を, 全身性肥満細胞症 (SM) という。本症例は肥満細胞の集簇が骨髄におい てのみ確認されていることから，診断基準およ び臨床経過より全身性慢性肥満細胞症indolent systemic mastocytosis（ISM）の亜型であるisolated bone marrow mastocytosisに相当するもの 
と思われる ${ }^{1,2)}$. SMでは, 一般に肥満細胞の臟器 浸潤による症状と, 肥満細胞からのメディエー ター放出による症状を呈するとされる ${ }^{3)}$. しかし 本症例は, 発作時の主な症状, 所見が腹痛, 凝 固異常などメディエーターによる症状としては 典型的ではなく,さらにほとんどのISMで認める とされる皮膚症状を欠き4), 病変が骨髄に限局し ていたため診断に苦慮した。本症例での著しい 凝固異常はその異常が常に一過性であったこと より肥満細胞から放出されたへパリン様物質に よって引き起こされた可能性が考えられた ${ }^{3,5}$. また, 低血圧, 腹痛や下痢は, 肥満細胞から放 出されたヒスタミン，ロイコトリエン，セロト ニンなどによって引き起こされた可能性がある ${ }^{3)}$. 診断にはトリプターゼ測定や骨髄検查が有用で あるが( 3)骨髄の病巣が局在している場合があり, 一度の骨髄検査では十分に診断できないことも あるため, トリプターゼが高值である場合は, 繰り返し骨髄検查を行うべきである ${ }^{6)}$. 本症例で も，三度骨髄穿刺検査を施行したが病変が比較 的広く認められたのは一度のみであった，本症 例では初回発作時の出血症状が顕著であったた め, 凝固異常の存在が確認されたが, 出血症状 がなくてもへパリン血症による凝固異常は程度 の差はあれ，多くの症例で存在すると思われ， 留意する必要があると思われる. 本症例は現在, 抗ヒスタミン剤，メディエーター遊離抑制剤な
どの投与で発作の程度が減り, 発作時の症状も 軽減している. ISMは一般に予後良好とされる が7), 本症例では発作時の凝固異常が生命を脅か す可能性もあり，出血症状を繰り返す場合は, 今後, ステロイド剤や肥満細胞を減少させる治 療 $3,7,8)$ も検討する必要があると思われた。

\section{文献}

1) Jaffe WS, et al : World health organization classification of tumors: Pathology and genetics, tumor of hematopoietic and lymphoid tissues. IARC Press, Lyon, 2001, 292302.

2) Valent $P$, et al: Diagnostic criteria and classification of mastocytosis. A consensus proposal. Leuk Res 25 : 603625, 2001.

3) Valent $P$, et al: Diagnosis and treatment of systemic mastocytosis. State of the art. Br J Haematol 122 : 695-717, 2003.

4) Metcalfe DD : Classification and diagnosis of mastocytosis : current status. J Invest Dermatol 96 : 2S-4S, 1991.

5) Hansen U, et al: Shock and coagulation disorders in systemic mastocytosis. Dtsch Med Wochenschr 119 : 12311234, 1994.

6) Pardanani A : Systemic mastocytosis : bone marrow pathology, classification, and current therapies. Acta Haematol 114: 41-51, 2005.

7) Florian $\mathrm{S}$, et al : Indolent systemic mastocytosis with elevated serum tryptase, absence of skin lesion, and recurrent severe anaphylactoid episodes. Int Arch Allergy Immunol 136 : 273-280, 2005.

8) Pardanani A, et al: Imatinib for systemic mast-cell disease. Lancet 362 : 535-537, 2003. 